\title{
ECONOMIC GROWTH MODELS AND GOVERNMENT EXPENDITURE IN SOUTH AFRICA: A DISAGGREGATED IMPACT ANALYSIS
}

\author{
Ifeoma Anthonia Iwegbunam \\ University of South Africa, Pretoria Campus. \\ Department of Economics, University of South Africa, Main Campus, Muckleneuk, \\ Pretoria. \\ 57832064@mylife.unisa.ac.za \\ Orcid no: 0000-0001-8893-1384

\section{Zurika Robinson} \\ University of South Africa, Pretoria Campus. \\ Department of Economics, University of South Africa, Main Campus, Muckleneuk, \\ Pretoria. \\ RobinZ@unisa.ac.za \\ Orcid no: 0000-0001-6375-7535
}

\section{-Abstract -}

This study examined the effects of government expenditure on different components of economic growth in South Africa. The six key policy variables employed in the analysis were derived from the Solow neoclassical growth model and the New Growth Path (NGP), a macroeconomic framework designed to address the main challenges (unemployment, poverty and inequality) facing the economy as a result of its political past. The analysis of the relationship was carried out using the cointegration model, longrun estimates and the VECM, because assessing the effects of government expenditure on economic growth goes beyond the short-term period, due to the fact that it takes time before government outlays have an effect on the economy. The findings from the analysis revealed that though there exists a long-run equilibrium relationship among the variables with the cointegration results, the long-run estimates showed that aggregate private consumption expenditure and employment-to-population ratio are significantly, but negatively, related to economic growth, while net inflows of foreign direct investment and gross fixed capital formation are negatively related to gross government expenditure. This implies that government needs to direct most of its spending towards human capital development, in order to overcome the challenges. However, government expenditure needs to be monitored, since excessive public capital expenditure might reduce the positive impact of foreign direct investment on economic growth. The study therefore suggests that government should consider increasing its expenditure on 
the significant variables that support labour and capital development, in order to enhance economic growth in South Africa.

Key Words: Government expenditure, economic growth models, government policy, VECM, South Africa

\section{JEL Classification: H53, H54, G28, C32, O10.}

\section{Introduction and background}

Since the dawn of democracy in South Africa, economic policy has been preoccupied with the issue of an all-inclusive and balanced growth, which gives priority to increasing economic performance. Although government has continued to design policies that will help to curb the three main challenges facing the economy, namely unemployment, poverty and inequality, the ripple effects associated with the country's political past have continued to jeopardise these efforts. Again, the gap between the sophisticated formal economy and the second informal economy, which is characterised by the three main challenges keep on widening. Therefore, the quest for equitable and sustainable economic conditions for the previously marginalised majority has challenged the structure of government expenditure in South Africa. This implies that it will be imperative to reassess the level of relationship between government expenditure and the key policy variables in South Africa.

Government expenditure, as the instrument for economic adjustment, is well known for having an effect on economic growth (Kolawole \& Odubunmi, 2015:444). However, economic adjustment can only happen with productive growth models. The better known growth model theorists, such as Harrod-Domar (1939; 1946), Solow and Swan (1956), Romer (1986) and Lucas (1988), amongst others, all came to the conclusion respectively that capital accumulation, labour, technology and innovation through research and development are the main components of economic growth. Building on these growth models, Barro (1990) designed a model of government expenditure in a theory of endogenous growth, whereby the long-run rate of growth depends on the structure of government expenditure, which is classified as being either productive or non-productive. This implies that for government expenditure to achieve the desired economic performance, models that apply to a country's specific needs have to be considered. Literature from Wu et al., (2010) and Agostino et al., (2016) conducted in relation to developed and developing countries support these views and explain that the growth models adopted by developed economies might not yield the same favourable results in the developing world. In the South African context, not much was done to extend increased government expenditure to the black majority in the country during the pre-1994 period. However, after independence, 
government expenditure, both recurrent and capital, increased significantly due to various macroeconomic policies, namely RDP, GEAR, ASGISA, NGP and the NDP, which were designed by government to make the economy all-inclusive (Moyo and Mamabolo, 2014). The overall government consumption expenditure as a percentage of GDP in South Africa was 13\% in 1970, which was the lowest for the period 1970 to 2016. Thereafter, it increased to $14 \%$ in $1980,20 \%$ in 1990 , and reached an all-time high (since 1960) of $21 \%$ in 2009.

Within the fiscal years of 2013 and 2014, the overall budget rose to R1.15 trillion, with R682 billion being allocated to social spending, which includes education, health, housing and social grants, amongst others. This expenditure increase is in line with global studies like Carter, (2013) and Suanin, (2015) which support the theory of a positive relationship between government expenditure and improved economic growth. Among the intervention policies developed in the post-apartheid era is the New Growth Path (NGP), an initiative developed by the government in 2010, with the aim of creating more employment opportunities and reducing unemployment by $10 \%$ by 2020 (Zarenda, 2013). Based on Vernon's product life cycle theory (1993), Ajudua and Ojima, (2015) and Kolawole and Odubunmi, (2015) have opposing views on the importance of FDI as an avenue for the transfer of technology and whether it contributes more to economic performance than domestic investment. In terms of the gross fixed capital formation, Gibeseu (2010) and Uneze (2013) identified the existence of a cointegrating relationship between government expenditure and capital formation. The employment-to-population ratio was considered based on the assumptions that the factors of production require human capital in either the process of product development or in providing services to meet aggregate demands (Ajakaiye et al., 2016). Investigating Keynes' (1936) proposed link between aggregate private consumption expenditure, studies such as Karim et al. (2010) and Nasir (2012) amongst others supported the argument regarding the importance of household consumption in increasing productivity levels and enhancing economic performance.

Empirical studies conducted in relation to the South African economy (Fedderke et al., 2006; Chipaumire et al., 2014; Mosikari and Matlwa, 2014 and Odhiambo, 2015) provide an in-depth analysis of the relationship between aggregate and disaggregated government expenditure and economic growth, or their direction of causality, but do not consider whether the South African government is applying an effective policy framework. This implies that previous studies have not helped to answer the question as to how government will be able to identify the core areas where increased expenditure can be most productively employed, in order to curb the inefficiencies existing in the economy. To examine whether government outlays are directed 
towards the right policy framework, the existence of a long-run relationship among the variables needs to be established, and whether the relationship is positive or not. Moreover, isolating the precise effects of government expenditure on aggregate economic performance might be impossible without considering the structure of this expenditure. In this regard, results have been somewhat inconclusive, which has left gaps that need to be filled in terms of understanding the effects of government expenditure on different components of economic growth in South Africa. This study is different from other studies, in that it empirically examined the externality effects of government expenditure on the adopted key policy variables, as contained in the NGP (2010) and Solow's neoclassical growth model.

The remainder of the study is arranged as follows: section 2 presents the theoretical framework, methodology and estimation techniques used in the study, as well as the data analysis. The estimation results are discussed in section 3, and section 4 concludes the study with policy recommendations.

\section{Theoretical framework, methodology and data analysis}

\subsection{Theoretical Framework}

The theoretical framework adopted for this study is the Solow neoclassical growth model, which was developed by Solow and Swan (1956). The ideology behind the model is that all countries possess identical aggregate production functions, and that the three factors that drive economic growth in any economy are technology, capital, and the labour force. This means that economies will conditionally converge at the same level of income, if they have the same rate of savings, depreciation, labour force growth and productivity growth (Durlauf et al., 2001). Liu (2007) and Keita (2016) employed this framework to analyse models of economic growth in South Africa and other African countries, and concluded that much still needs to be done in terms of improving human capital accumulation through research and development. Thus, the equation for the Solow neoclassical growth model is given as:

$$
\Delta k=s f(k)-(\delta+n) k
$$

The growth of the capital-labour ratio is represented by $k$, which is regarded as capital deepening in the model. It shows that the growth of $k$ depends on savings $s f(k)$, after allowing for the amount of capital required to service depreciation, $\delta k$, and providing the existing amount of capital per worker to net new workers joining the labour force, $n k$. 
For the purpose of this study, the variables estimated were derived from the Solow neoclassical growth model and the NGP key policy variables. Thus, the variables adopted in this study are as follows: gross government expenditure, aggregate private consumption expenditure, gross fixed capital formation, employment to population ratio, and net inflows of foreign direct investment due to their relationship with the structure of the South African economy.

\subsection{Methodology}

This study adopted the vector error correction mechanism (VECM) by Johansen (1995). The reason for choosing this technique is that assessing the effects of government expenditure on economic growth models goes beyond the short-term, since it takes time before government outlays have an effect on the economy. The procedure for using the VECM technique starts with the unit root test, in order to determine if the variables are of order 1[0] or 1[1]. This study conducted the unit root test using both the Augmented Dickey Fuller (ADF) $(1971,1981)$ approach and the Philips-Perron (PP) (1988) approach. The cointegration analysis introduced by Granger (1981) and Engle and Granger (1987), and then Johansen and Juselius (1990), was employed. The model assumes that if two integrated variables share a common stochastic trend, such that a linear combination of these variables is stationary, then there is the presence of cointegration (Lutkepohl and Kilian, 2016).

In a situation whereby the variables under consideration are cointegrated, the vector error correction model (VECM) will be applied in the model to evaluate the properties of the cointegrated series, as done in this study. Based on the cointegration test performed, longrun estimates were used to further detect the magnitude of these relationships.

From the Solow neoclassical model in equation 2.1 and the NGP models, the estimation model for this study was specified as follows:

$G D P=F(P E X P, G E X P, C A P, L A B, F D I)$

The equation above implies that gross domestic product is a function of PEXP, GEXP, CAP, LAB, and FDI. In other words, GDP is the dependent variable, while PEXP , GEXP , CAP, LAB, FDI are the independent variables. To represent all those factors that affect government expenditure, but which were not explicitly taken into account, the error term is introduced into the model. From equation (2.2), the model specification is given as: 
$G D P=\beta_{0}+\beta_{1} P E X P+\beta_{2} G E X P+\beta_{3} C A P+\beta_{4} L A B+\beta_{5} F D I+\varepsilon_{t}$ (2.3)

In light of the model specified above, the variables used in this study are as follows: aggregate private consumption expenditure proxy for household consumption expenditure (PEXP), gross government expenditure proxy for total government expenditure (GEXP recurrent and capital), gross fixed capital formation proxy for physical capital stock (CAP), employment to population ratio proxy for level of employment (LAB), and net inflows of foreign direct investment proxy for technology transfer (FDI).

To control for huge disparities among the series, all the variables were transformed into logarithms. Therefore, the model will be a log-linear model, and equation (2.3) is expressed as follows:

$L N_{-} G D P_{t}=\beta_{0}+\beta_{1} L N_{-} P E X P_{t}+\beta_{2} L N_{-} G E X P_{t}+\beta_{3} L N_{-} C A P_{t}+\beta_{4} L N_{-} L A B_{t}+\beta_{5} F D I_{t}$ $+\varepsilon_{t}$

(2.4)

Where $G D P_{t}$ is the growth rate of the real GDP in time $t$ as a measure of economic growth, $P E X P_{t}$ represents the aggregate private consumption expenditure at time t, GEXP $_{t}$ is the gross government expenditure at time ${ }_{\mathrm{t}}, C A P_{t}$ is the gross fixed capital formation at time ${ }_{\mathrm{t},} L A B_{t}$ is the employment-to-population ratio at time ${ }_{\mathrm{t},} F D I_{t}$ represents the net inflows of foreign direct investment at time ${ }_{t}$, and $\varepsilon_{t}$ is the error term of the stochastic variable, which considers inexact relationships between economic variables. $\beta_{0}, \beta_{1}, \beta_{2}, \beta_{3}, \beta_{4}$ and $\beta_{5}$ are the unknown parameters to be estimated.

\subsection{Data analysis}

The empirical analysis carried out in this study employed quarterly time series data which covers the period 1970Q1 to 2016Q4, based on the availability of data. The data was sourced from the South African Reserve Bank database (2017). In addition, the method of extrapolation and interpolation was applied to generate the missing values in the series, since the data for net inflows of foreign direct investment (FDI) was only available from 1985 to 2016, whereas the study covered the period from 1970Q1 to 2016Q4.

\section{Empirical analysis}

\subsection{Unit root test results}


Applying empirical techniques to time-series data requires an analysis of the time series properties of the variables, in order to determine the order of integration for multivariate series. Table 1 below presents the unit root test results for the variables that were considered.

Table 1: Unit root test results

\begin{tabular}{|c|c|c|c|c|c|c|c|}
\hline \multirow[b]{2}{*}{ Series } & \multirow[b]{2}{*}{ Model } & & \multicolumn{2}{|l|}{ ADF } & \multicolumn{2}{|l|}{$\mathbf{P P}$} & \multirow[b]{2}{*}{$\begin{array}{l}\text { Order of integration } \\
\text { I(d) }\end{array}$} \\
\hline & & & Level & $\begin{array}{l}\text { First } \\
\text { difference }\end{array}$ & Level & First difference & \\
\hline \multirow[t]{3}{*}{ GDP } & None & & $\begin{array}{l}4.314276 \\
(1.0000)\end{array}$ & $\begin{array}{l}-4.997578 * * * \\
(0.0000)\end{array}$ & $\begin{array}{l}4.355800 \\
(1.0000)\end{array}$ & $\begin{array}{l}-8.672438 * * * \\
(0.0000)\end{array}$ & $\mathrm{I}(1)$ \\
\hline & Constant & & $\begin{array}{l}-0.412420 \\
(0.9033)\end{array}$ & $\begin{array}{l}-10.35813 * * * \\
(0.0000)\end{array}$ & $\begin{array}{l}-0.592723 \\
(0.8681)\end{array}$ & $\begin{array}{l}-10.61092 * * * \\
(0.0000)\end{array}$ & I(1) \\
\hline & $\begin{array}{l}\text { Constant } \\
\text { trend }\end{array}$ & and & $\begin{array}{l}-1.553294 \\
(0.8075)\end{array}$ & $\begin{array}{l}-10.33125 * * * \\
(0.0000)\end{array}$ & $\begin{array}{l}-1.734960 \\
(0.7319)\end{array}$ & $\begin{array}{l}-10.58704 * * * \\
(0.0000)\end{array}$ & I(1) \\
\hline \multirow[t]{3}{*}{ PEXP } & None & & $\begin{array}{l}-2.029204 * * \\
(0.0410)\end{array}$ & $\begin{array}{l}-1.180606 \\
(0.2169)\end{array}$ & $\begin{array}{l}-5.464660 * * * \\
(0.0000)\end{array}$ & $\begin{array}{l}-3.123529 * * * \\
(0.0019)\end{array}$ & I(1) \\
\hline & Constant & & $\begin{array}{l}-6.065199 * * * \\
(0.0000)\end{array}$ & $\begin{array}{l}-4.171983 * * * \\
(0.0010)\end{array}$ & $\begin{array}{l}-4.033385 * * * \\
(0.0016)\end{array}$ & $\begin{array}{l}-11.83457 * * * \\
(0.0000)\end{array}$ & I(1) \\
\hline & $\begin{array}{l}\text { Constant } \\
\text { trend }\end{array}$ & and & $\begin{array}{l}2.127086 \\
(1.0000)\end{array}$ & $\begin{array}{l}-11.80735 * * * \\
(0.0000)\end{array}$ & $\begin{array}{l}1.213280 \\
(1.0000)\end{array}$ & $\begin{array}{l}-12.62323 * * * \\
(0.0000)\end{array}$ & I(1) \\
\hline \multirow[t]{3}{*}{ GEXP } & None & & $\begin{array}{l}-3.962626 * * * \\
(0.0001)\end{array}$ & $\begin{array}{l}-2.290501 * * \\
(0.0216)\end{array}$ & $\begin{array}{l}-9.916996 * * * \\
(0.0000)\end{array}$ & $\begin{array}{l}-11.19561 * * * \\
(0.0000)\end{array}$ & I(1) \\
\hline & Constant & & $\begin{array}{l}-4.476359 * * * \\
(0.0003)\end{array}$ & $\begin{array}{l}-5.223749 * * * \\
(0.0000)\end{array}$ & $\begin{array}{l}-4.150595 * * * \\
(0.0010)\end{array}$ & $\begin{array}{l}-15.16693 * * * \\
(0.0000)\end{array}$ & I(1) \\
\hline & $\begin{array}{l}\text { Constant } \\
\text { trend }\end{array}$ & and & $\begin{array}{l}0.496655 \\
(0.9993)\end{array}$ & $\begin{array}{l}-13.03684 * * * \\
(0.0000)\end{array}$ & $\begin{array}{l}0.159997 \\
(0.9976)\end{array}$ & $\begin{array}{l}-16.53575 * * * \\
(0.0000)\end{array}$ & I(1) \\
\hline \multirow[t]{3}{*}{ CAP } & None & & $\begin{array}{l}-4.874861 * * * \\
(0.0000)\end{array}$ & $\begin{array}{l}-3.216789 * * * \\
(0.0014)\end{array}$ & $\begin{array}{l}-7.475165 * * * \\
(0.0000)\end{array}$ & $\begin{array}{l}-9.279811 * * * \\
(0.0000)\end{array}$ & I(1) \\
\hline & Constant & & $\begin{array}{l}-1.812439 \\
(0.3736)\end{array}$ & $\begin{array}{l}-7.184414 * * * \\
(0.0000)\end{array}$ & $\begin{array}{l}-2.226990 \\
(0.1975)\end{array}$ & $\begin{array}{l}-12.52570 * * * \\
(0.0000)\end{array}$ & I(1) \\
\hline & $\begin{array}{l}\text { Constant } \\
\text { trend }\end{array}$ & and & $\begin{array}{l}-2.756556 \\
(0.2155)\end{array}$ & $\begin{array}{l}-7.393234 * * * \\
(0.0000)\end{array}$ & $\begin{array}{l}-2.405193 \\
(0.3757)\end{array}$ & $\begin{array}{l}-12.65194 * * * \\
(0.0000)\end{array}$ & I(1) \\
\hline \multirow[t]{3}{*}{ LAB } & None & & $\begin{array}{l}2.574725 \\
(0.9977)\end{array}$ & $\begin{array}{l}-5.034397 * * * \\
(0.0000)\end{array}$ & $\begin{array}{l}3.324823 \\
(0.9998)\end{array}$ & $\begin{array}{l}-8.305290 * * * \\
(0.0000)\end{array}$ & I(1) \\
\hline & Constant & & $\begin{array}{l}-3.261152 * * \\
(0.0182)\end{array}$ & $\begin{array}{l}-5.797297 * * * \\
(0.0000)\end{array}$ & $\begin{array}{l}-4.217216 * * * \\
(0.0008)\end{array}$ & $\begin{array}{l}-9.414036 * * * \\
(0.0000)\end{array}$ & I(1) \\
\hline & $\begin{array}{l}\text { Constant } \\
\text { trend }\end{array}$ & and & $\begin{array}{l}-2.303753 \\
(0.4294)\end{array}$ & $\begin{array}{l}-6.363741 * * * \\
(0.0000)\end{array}$ & $\begin{array}{l}-2.623896 \\
(0.2703)\end{array}$ & $\begin{array}{l}-9.998850 * * * \\
(0.0000)\end{array}$ & I(1) \\
\hline \multirow[t]{3}{*}{ FDI } & None & & $\begin{array}{l}-2.615975 * * * \\
(0.0090)\end{array}$ & $\begin{array}{l}-12.04296 * * * \\
(0.0000)\end{array}$ & $\begin{array}{l}-9.880227 * * * \\
(0.0000)\end{array}$ & $\begin{array}{l}-95.28429 * * * \\
(0.0001)\end{array}$ & I(1) \\
\hline & Constant & & $\begin{array}{l}-6.450786 * * * \\
(0.0000)\end{array}$ & $\begin{array}{l}-12.01347 * * * \\
(0.0000)\end{array}$ & $\begin{array}{l}-10.84343 * * * \\
(0.0000)\end{array}$ & $\begin{array}{l}-104.1280 * * * \\
(0.0001)\end{array}$ & I(1) \\
\hline & $\begin{array}{l}\text { Constant } \\
\text { trend }\end{array}$ & and & $\begin{array}{l}-12.25480 * * * \\
(0.0000)\end{array}$ & $\begin{array}{l}-11.97953 * * * \\
(0.0000)\end{array}$ & $\begin{array}{l}-12.27131 * * * \\
(0.0000)\end{array}$ & $\begin{array}{l}-102.9827 * * * \\
(0.0001)\end{array}$ & $\mathbf{I}(\mathbf{1})$ \\
\hline
\end{tabular}

Notes: $\quad$ Null: Unit root (Automatic - based on SIC, maxlag=14): ADF (t-statistic)

Null: Unit root (Newey-West automatic using Bartlett kernel): PP (adjusted t-statistic) $* * *, * *$ and $*$ are $1 \%, 5 \%$ and $10 \%$ significance levels respectively

Source: Author's calculation using Eviews 7. 
The results revealed that the GDP, PEXP, GEXP, CAP and LAB are not stationary at level, but FDI is stationary at level in both ADF and PP unit root tests. This implies that there is the presence of random walk stochastic components in the non-stationary models, and an attempt to use them for estimation at level would lead to spurious regressions. Further unit root tests at first difference showed that the series are stationary, that is, integrated of order [1(1)] at first difference, with a 99 percent confidence level, which suggests the possible existence of a long-run equilibrium among the series used.

\subsection{Cointegration test}

Since the main objective of this study is to estimate the nature of the relationship between GEXP, PEXP, CAP, LAB AND FDI as well as how they impact the GDP.

\section{Table 2: Cointegration test results}

\begin{tabular}{|c|c|c|c|c|c|c|}
\hline \multicolumn{4}{|c|}{ Trace test } & \multicolumn{3}{|c|}{ Maximum Eigen value test } \\
\hline $\mathbf{H}_{\mathbf{0}}$ & $\mathbf{H}_{1}$ & $\lambda$-trace statistic & p-value & $\mathbf{H}_{\mathbf{0}}$ & $\mathbf{H}_{1}$ & $\lambda$-max statistic \\
\hline \multicolumn{7}{|c|}{ GDP, PEXP, GEXP, CAP, LAB and FDI } \\
\hline $\mathrm{r}=0$ & $\mathrm{r} \geq 1$ & 202.9419 & $0.0000^{*}$ & $\mathrm{r}=0$ & $\mathrm{r} \geq 1$ & 68.39722 \\
\hline $\mathrm{r} \leq 1$ & $r \geq 2$ & 134.5446 & $0.0000 *$ & $\mathrm{r} \leq 1$ & $\mathrm{r} \geq 2$ & 64.34618 \\
\hline$r \leq 2$ & $\mathrm{r} \geq 3$ & 70.19847 & $0.0014^{*}$ & $\mathrm{r} \leq 2$ & $\mathrm{r} \geq 3$ & 37.83343 \\
\hline $\mathrm{r} \leq 3$ & $r \geq 4$ & 32.36504 & $0.0934 *$ & $\mathrm{r} \leq 1$ & $\mathrm{r} \geq 2$ & 18.01199 \\
\hline$r \leq 4$ & $\mathrm{r} \geq 5$ & 14.35305 & 0.1680 & $\mathrm{r} \leq 2$ & $\mathrm{r} \geq 3$ & 14.12117 \\
\hline$r \leq 5$ & $\mathrm{r} \geq 6$ & 0.231877 & 0.6301 & $\mathrm{r} \leq 2$ & $\mathrm{r} \geq 3$ & 0.231877 \\
\hline
\end{tabular}

Notes: *Rejection of the null hypothesis of no cointegration at least at $10 \%$ level of significance. Source: Author's calculation using Eviews 7.

Applying the cointegration test can assist in detecting the type of relationship that exists among the variables. The empirical findings in Table 2 revealed that at least three cointegrating vectors of PEXP, GEXP, CAP, LAB and FDI show the presence of 
cointegration. The trace statistic and maximum Eigen statistic showed that seven out of the twelve equations are statistically significant from at least the 10 percent significance level. Therefore, the study does not accept the null hypothesis that there is no cointegration. This indicates that allowing for a linear trend, there is a long-run equilibrium relationship among these variables. The implication of the findings from the cointegration test is that the variables are closely related and have the ability to assert either negative or positive effects on each other in the long-run.

\subsection{Long-run estimates}

The long-run estimates was applied to detect the magnitude of the long-run equilibrium relationship among

\section{Table 3: Long-run estimates results}

\begin{tabular}{|c|c|c|}
\hline \multirow[b]{2}{*}{ Independent variable } & \multicolumn{2}{|c|}{ Dependent variable } \\
\hline & GDP; & GEXP \\
\hline Constant & $\begin{array}{l}3.444707 * * * \\
{[15.75018]^{* * *}} \\
(0.0000)\end{array}$ & $\begin{array}{l}-5.431860 * * * \\
{[-10.47536] * * *} \\
(0.0000)\end{array}$ \\
\hline GDP & 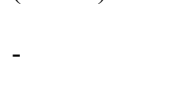 & $\begin{array}{l}0.293111 * * \\
{[2.048234]} \\
(0.0420)\end{array}$ \\
\hline PEXP & $\begin{array}{l}-0.240941 * * * \\
{[-6.138515]} \\
(0.0000)\end{array}$ & $\begin{array}{l}1.057884 * * * \\
{[34.47250]} \\
(0.0000)\end{array}$ \\
\hline GEXP & $\begin{array}{l}0.076870 * * \\
{[2.048234]} \\
(0.0420)\end{array}$ & - \\
\hline CAP & $\begin{array}{l}0.421039 * * * \\
{[37.10637]} \\
(0.0000)\end{array}$ & $\begin{array}{l}-0.135198 * * * \\
{[-2.110272]} \\
(0.0362)\end{array}$ \\
\hline LAB & $\begin{array}{l}-0.426755 * * * \\
{[-10.81166]} \\
(0.0000)\end{array}$ & $\begin{array}{l}0.828773 * * * \\
{[10.71513]} \\
(0.0000)\end{array}$ \\
\hline FDI & $\begin{array}{l}0.204929 \\
{[0.745349]} \\
(0.4570)\end{array}$ & $\begin{array}{l}-0.613498 \\
{[-1.145063]} \\
(0.2537)\end{array}$ \\
\hline $\begin{array}{l}\text { R-squared } \\
\text { F-statistic }\end{array}$ & $\begin{array}{l}0.993455 \\
5524.826 \\
(0.000000)\end{array}$ & $\begin{array}{l}0.999319 \\
53433.48 \\
(0.000000)\end{array}$ \\
\hline
\end{tabular}

Notes: Values in parentheses [ ] and ( ) are t-statistics and p-value. $* * *, * *$ and $*$ are $1 \%, 5 \%$ and $10 \%$ significance level respectively

Source: Author's calculation using Eviews 7. 
the variables. In terms of the real (GDP), the results show that all the variables, except PEXP and LAB have a positive impact on real GDP. The results also reveal that a $1 \%$ decrease in PEXP leads to a 0.241 percent decrease in real GDP. The findings from the coefficient of GEXP show that a $1 \%$ rise in GEXP leads to a 0.077 percent increase in real GDP, and that a one percent increase in CAP causes a 0.421 percent increase in real GDP. Moreover, a $1 \%$ decrease in LAB leads to 0.427 percent decrease in real GDP. On the other hand, a $1 \%$ rise in FDI causes a $0.204 \%$ increase in real GDP. The negative relationship that existed in this study between PEXP, LAB and GDP does not conform to apriori expectations but portrayed the current situation of the South African economy. The individual significance test of the explanatory variables for the economic growth model revealed that all the other variables, except for FDI, are statistically significant in relation to real GDP at the 1\% significance level, and that GEXP is statistically significant at the 5\% significance level in relation to real GDP. However, FDI is not statistically significant at the $10 \%$ significance level in relation to real GDP. This implies that all the other variables assert pressure on GDP, while FDI does not. The coefficient of determination revealed that the explanatory variables caused 99.346 percent variations in real GDP, but the stochastic components caused 0.654 percent variations in real GDP. This represents a goodness of fit for the model.

The results for GEXP revealed that GDP, PEXP, and LAB have a positive impact and statistical significance of at least $5 \%$ on GEXP, while CAP is negatively related and statistically significant at the $1 \%$ level, and FDI is negatively related and statistically insignificant to GEXP within the period under investigation.

Meanwhile, a $1 \%$ increase in them causes a $0.293,1.058$ and 0.829 percent increase in GEXP respectively, but a $1 \%$ increase in CAP and FDI respectively leads to a 0.135 and 0.613 percent decrease in GEXP.

The joint significance test of the explanatory variables revealed that they are all jointly and statistically significant at the 1\% significance level to GEXP. The goodness of fit test of the model revealed that all the variables cause 99.932 percent variations in GEXP, but the error term causes 0.068 percent variations in GEXP.

\subsection{VECM test}

This test is used to evaluate the cointegration results and the speed adjustment of equilibrium. Thus, if the VECM is negative 
INTERNATIONAL JOURNAL OF ECONOMICS AND FINANCE STUDIES

Vol 11, No 1, 2019 ISSN: 1309-8055 (Online)

Table 4: VECM test results

\begin{tabular}{|c|c|c|}
\hline \multirow[t]{2}{*}{ Independent variable } & \multicolumn{2}{|c|}{ Dependent variable } \\
\hline & GDP & GEXP \\
\hline \multirow[t]{3}{*}{ Constant } & 0.000763 & 0.049341 \\
\hline & {$[0.31499]$} & [5.14604] \\
\hline & $(0.7532)$ & $(0.0000)$ \\
\hline \multirow[t]{3}{*}{$\mathbf{G D P}_{t-1}$} & 0.129393 & 0.103791 \\
\hline & [ 1.77540$]$ & {$[0.35961]$} \\
\hline & $(0.0776)$ & $(0.7196)$ \\
\hline \multirow{3}{*}{$\mathbf{G D P}_{\mathrm{t}-2}$} & 0.059087 & 0.463801 \\
\hline & {$[0.80793]$} & [1.60139] \\
\hline & $(0.4203)$ & $(0.1111)$ \\
\hline \multirow{3}{*}{$\operatorname{PEXP}_{t-1}$} & 0.070380 & 0.226684 \\
\hline & [ 1.39192$]$ & {$[1.13206]$} \\
\hline & $(0.1658)$ & $(0.2592)$ \\
\hline \multirow[t]{3}{*}{ PEXP $_{t-2}$} & 0.029792 & -0.061330 \\
\hline & {$[0.58663]$} & {$[-0.30495]$} \\
\hline & $(0.5582)$ & $(0.7608)$ \\
\hline \multirow{3}{*}{$\operatorname{GEXP}_{t-1}$} & 0.007369 & -0.338007 \\
\hline & {$[0.39251]$} & {$[-4.54613]$} \\
\hline & $(0.6952)$ & $(0.0000)$ \\
\hline \multirow[t]{3}{*}{$\operatorname{GEXP}_{t-2}$} & -0.022894 & -0.341943 \\
\hline & {$[-1.22465]$} & {$[-4.61880]$} \\
\hline & $(0.2224)$ & $(0.0000)$ \\
\hline \multirow[t]{3}{*}{$\mathrm{CAP}_{t-1}$} & -0.013328 & -0.060139 \\
\hline & {$[-0.68810]$} & {$[-0.78403]$} \\
\hline & $(0.4923)$ & $(0.4341)$ \\
\hline \multirow[t]{3}{*}{$\mathbf{C A P}_{\mathrm{t}-2}$} & 0.000763 & -0.042407 \\
\hline & [0.04087] & {$[-0.57358]$} \\
\hline & $(0.9675)$ & $(0.5670)$ \\
\hline \multirow[t]{3}{*}{$\mathbf{L A B}_{\mathbf{t}-1}$} & 0.353851 & 0.492042 \\
\hline & [4.04601] & [1.42067] \\
\hline & $(0.0001)$ & $(0.1572)$ \\
\hline \multirow{3}{*}{$\mathbf{L A B} \mathbf{B}_{\mathrm{t}-2}$} & 0.115661 & 0.165991 \\
\hline & [ 1.24314$]$ & {$[0.45051]$} \\
\hline & $(0.2155)$ & $(0.6529)$ \\
\hline \multirow[t]{3}{*}{ FDI $_{t-1}$} & 0.056469 & 0.017421 \\
\hline & {$[0.80793]$} & {$[0.06294]$} \\
\hline & $(0.4203)$ & $(0.9499)$ \\
\hline \multirow{3}{*}{ FDI $_{t-2}$} & 0.043021 & 0.126404 \\
\hline & [0.61043] & [0.45289] \\
\hline & $(0.5424)$ & $(0.6512)$ \\
\hline \multirow[t]{3}{*}{$\mathbf{E C M}_{t-1}$} & -0.049393 & 0.223108 \\
\hline & {$[-3.47179]^{* * *}$} & {$[3.95990]^{* * *}$} \\
\hline & $(0.0007)$ & $(0.0001)$ \\
\hline R-squared & 0.259728 & 0.244751 \\
\hline \multirow[t]{2}{*}{ F-statistic } & 4.615094 & 4.262725 \\
\hline & $(0.000001)$ & $(0.000004)$ \\
\hline
\end{tabular}

Notes: Values in parentheses [ ] and ( ) are t-statistics and p-value. $* * *, * *$ and $*$ are $1 \%, 5 \%$ and $10 \%$ significance level respectively 


\section{Source: Author's calculation using Eviews 7.}

and significant, there is a long-run equilibrium and causality running from regressors to regressand. However, if the result is otherwise, there is no long-run equilibrium. The empirical results for real GDP showed that the VECM is negative and statistically significant at the $1 \%$ significance level. Therefore, there is a long-run equilibrium relationship and causality running from the regressors, namely PEXP, GEXP, CAP, LAB and FDI, to the regressand - GDP.

The GEXP model estimations showed that the VECM is positive and statistically significant, hence there is no long-run causality running from real GDP, PEXP, CAP, $\mathrm{LAB}$ and FDI to GEXP. However, bivariate causality analysis suggested a strong influence of real GDP on GEXP.

\section{Conclusion and policy recommendations}

In this study, the externality effect of government expenditure on the different components of economic growth in South Africa was empirically established. To capture information from the apartheid era and post-apartheid regime, the data covered the period from 1970Q1 to 2016Q4, and variables were derived from the Solow neoclassical growth theory and the NGP framework, due to their applicability to the South African economy. The empirical results showed the level of disequilibrium existing before and after the policy change. This implies that although the economy has improved to some extent, it is not significant because the economy still demonstrates mixed performance marked by policy imbalances.

The unit root tests revealed that all the series are stationary that is, integrated of order [1(1)] at first difference. The cointegration results indicate the existence of a long-run equilibrium relationship among the variables. The long-run estimates showed that although all the variables are statistically significant, PEXP and LAB are negatively related to economic growth. On the other hand, CAP is statistically significant, but negatively related to GEXP, and FDI is also statistically insignificant and negatively related to GEXP. The VECM empirical results for real GDP showed that there is a longrun equilibrium relationship and causality running from the regressors, namely PEXP, GEXP, CAP, LAB and FDI, to the regressand - GDP. While the results for GEXP revealed that there is no long-run causality running from real GDP, PEXP, CAP, LAB and FDI to GEXP, bivariate causality analysis suggested a strong influence of real GDP on GEXP.

Overall, the findings in this study revealed the following: firstly, due to the existence of a long-run equilibrium relationship among the variables, they have the ability to impact on 
each other negatively or positively in the long-run. As shown in the long-run results, PEXP and LAB have the ability to increase growth levels in South Africa, due to their significant level, but this is not the case, as a result of their negative impact on economic growth.

Secondly, with regard to the negative relationship between FDI and GEXP, it shows that excessive government expenditure, if not balanced, has the potential to reduce the positive effects of FDI on economic performance. The implication of the above analysis is that government expenditure has not impacted much on the key policy variables examined in this study. However, this does not mean that the NGP (2010) and the Solow neoclassical growth model do not apply to the South African economy.

This study therefore highlights the need for balanced expenditure, especially in terms of improving human capital development by creating an enabling environment for skills acquisitions in the form of education, as well as innovation through research and development, especially from the grassroots. There is also the need to retrain teachers trained according to the old Bantu form of education, in order to achieve effective learning and development. In addition, functionality and various individual contributions need to be encouraged more, by checking various forms of transferred payments in South Africa.

Further studies can reduce the number of years covered, so as to avoid the problems associated with data generation and the possibility of shocks from previous regimes reflecting in recent findings.

\section{BIBLIOGRAPHY}

Agostino, G., Dunne, J.P. and Pieroni, L. (2016), "Government Spending, Corruption and Economic Growth,” World Development, Vol. 84, pp. 190-205.

Ajakaiye, O., Afeikhena, T.J, Nabena, D. and Associate, (2016), "Understanding the Relationship between Growth and Employment in Nigeria," Development Policy Research Unit: United Nations University (UNU- WIDER), pp. 1-32.

Ajudua, E.I. and Ojima, D.J.P. (2015), "Government Expenditure, Foreign Direct Investment and Economic Growth in Nigeria," Journal of Economics and Sustainable Development, Vol. 6, No. 8, pp. 79-84.

Barro, R. (1990), "Government Spending in a Simple Model of Endogenous Growth," The Journal of Political Economy, Vol. 98, No.5, pp. S103-S125.

Carter, J., Craigwell, R. and Lowe, S. (2013), "Government Expenditure and Economic Growth in a Small Open Economy: a Disaggregated Approach," Central Bank of Barbados, pp. 1-28. 
Chipaumire, G. and Associates, (2014), "The Impact of Government Spending on Economic Growth: A Case of South Africa," Mediterranean Journal of Social Sciences, Vol. 5, No. 1, pp. 109-118.

Daurlauf, S., Kourtellos, A. and Mankin, A. (2001), "The Local Solow Growth Model," European Economic Review, Vol. 45, No. 4-6, pp. 928-940.

Dickey, A.D. and Fuller, I.I.A. (1971), "Distribution of the Estimators for Autoregressive Time Series with Unit Root," Journal of American Statistical Association, Vol. 75, pp. 427-431.

Dickey, A.D. and Fuller, I.I.A. (1981), "Distribution of the Estimators for Autoregressive Time Series with Unit Root," Journal of American Statistical Association, Vol. 102, pp. 53-69.

Domar, E.D. (1946), "Capital Expansion, Rate of Growth and Employment," Econometrica, Vol. 14, pp. 137-147.

Engle, R.F. and Granger, C.W.J. (1987), "Cointegration and Error Correction: Representation, Estimation and Testing," Econometrica, Vol. 55, No. 2, pp. 257-276.

Fedderke, J., Perkins, P. and Luiz, J. (2006), "Infrastructural Investment in Long-Run Economic Growth: in South Africa," World Development Journal, Vol. 34, No. 6, pp. 1037-1059.

Gibeseu, O. (2010), "Does the Gross Fixed Capital Formation Represent a Factor for supporting the Economic Growth?" Munich Personal RePEc Archive (MPRA) Paper 50135, pp. 1-6.

Granger, C.W. (1981), "Testing for causality," Journal of Economic Dynamic and Control, Vol. 4, pp. 229-252.

Harrod, R.F. (1939), “An Essay in Dynamic Theory,” Economic Journal, Vol. 49, pp. 1433.

Johansen, S. and Juselius, K. (1990), "Maximum Likelihood Estimation and Inference on Cointegration with Applications to Money Demand," Oxford Bulletin of Economics and Statistics, Vol. 52, No. 2, pp. 169-210.

Karim, Z., Karim, B. and Zaidi, M. (2012), "Fixed Investment Household Consumption and Economic Growth: a Structural Vector Error Correction Model (SVECM) Study of Malaysia," International Journal of Business and Society, Vol. 13, No. 1, pp. 63-76. 
Keita, L. (2016), "Models of Economic Growth and Development in the Context of Human Capital Investment-The Way Forward for Africa," African Development, Vol. XLI, No. 1, pp.23-48.

Keynes, J.M. (1936), The General Theory of Interest, Employment and Money, McMillan: London.

Kolawale, B.O. and Odubunmi, S.A. (2015), "Government Capital Expenditure, Foreign Direct Investment and Economic Growth Relationship in Nigeria," Mediterranean Journal of Social Sciences, Vol. 6, No. 4, pp.444-453.

Liu, D. (2007), "Growth Theory and Application: the case South Africa", University of Pretoria: Department of Economics Working Paper 2007-14. South Africa.

Lucas, R. (1988), "On the Mechanics of Economic Development," Journal of Monetary Economics, Vol. 22 No.1, pp. 3-42.

Lutkepohl, H. and Killian, L. (2016), "Structural Vector Autoregressive Analysis," Cambridge University Press: Cambridge, pp. 73-105.

Mosikari, J. and Matlwa, K. (2014), "An Analysis of Defense Expenditure and Economic Growth in South Africa," A Mediterranean Journal of Social Sciences, Vol. 20, No. 5, pp. 2769-2776.

Moyo, T. and Mamobolo, M. (2014), "The National Development Programme (NDP): a Comparative Analysis with the Reconstruction and Development Programme (RDP), Growth Employment and Redistribution (GEAR) Programme and Accelerated and Shared Growth Initiative for South Africa (ASGISA)," Journal of Public Administration, Vol. 49, No. 3, pp. 946-959.

Nasir, Z.A. (2012), "Household Consumption and Economic Growth: Cointegration and Causality Analysis of Malaysia," International Journal of Business and Society, pp. 5670 .

National Planning Commission (2011), Diagnostic Overview of National Development Plan 2030, www.info.gov.za/views, [Accessed 22.08. 2017]

Odiahmbo, N.M. (2015), "Government Expenditure and Economic Growth in South Africa: an Empirical Investigation," Atlantic Economic Journal, Vol. 43, No. 3, pp. 393406.

Philips, P. and Perron, P. (1988), "Testing for a Unit Root in time series regression," Biometrika, Vol. 75, No. 2, pp. 335-346. 
Pleic, M. and Berry, A. (2009), "Employment and Economic Growth: Employment Elasticities in Thailand, Brazil, Chile and Argentina," Human Sciences Research Council, pp. 2-47.

Romer, P.M. (1986), "Increasing Returns and Long-Run Growth,” Journal of Political Economy, Vol. 94, No. 5, pp. 1002-1037.

South African Reserve Bank), (2017), Quarterly Bulletin on Economic Growth, http://www.resbank.co.za/economicreview/DecisionMaking/Pages/growthmeasures.aspx, [Accessed 20. 05. 2016]

Solow, R. M. (1956), "A Contribution to the Theory of Economic Growth," Quarterly Journal of Economics, Vol. 70, No. 1, pp. 65-94.

Suanin, W. (2015), "The Impact of Government Expenditure on Economic Growth in Thailand," International Conference on Trends in Economic, Humanities and Management; Singapore, pp. 112-116.

Swan, T.W. (1956), "Economic Growth and Capital Accumulation," Economic Record, Vol.32, pp. 334-361.

Uneze, E. (2013), "The Relationship between Capital Formation and Economic Growth: Evidence from Sub-Saharan Africa," Journal of Economic Policy Reform, Vol. 16, No. 3, pp. 272-286.

Vernon, R. (2013), International Investment and International Trade in Product Cycle: In Buckley P. (ed), Internalisation of the Firms, Academic Press, London.

$\mathrm{Wu}$, S., Tang, J. and Lin E. (2010), "The Impact of Government Expenditure on Economic Growth: How Sensitive to the Level of Development?" Journal of Policy Modeling, Vol. 32, No. 6, pp. 804-817.

Zarenda, H. (2013), "South Africa's National Development Plan and its Implications for Regional Development," Stellenbosch Tralac Working Paper No. D13WP01: 1-15. Stellenbosch. 